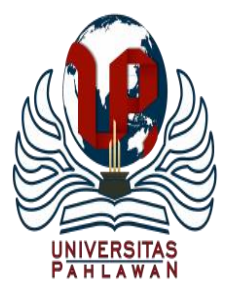

Jurnal Basicedu Volume 4 Nomor 4 Tahun 2020 Halaman 1315 - 1325

JURNAL BASICEDU

Research \& Learning in Elementary Education https://jbasic.org/index.php/basicedu

\title{
Pengaruh Strategi Pembelajaran Aktif Tipe Index Card Match Terhadap Hasil Belajar Peserta Didik di Sekolah Dasar
}

\author{
Ika Wulandari Utamining Tias ${ }^{1}$, Bella Dwi Putri ${ }^{2}$, Dian Pratiwi ${ }^{3}$ \\ Universitas Lampung, Lampung, Indonesia ${ }^{1,2,3}$ \\ E-mail : ika.wulandari84@fkip.unila.ac.id
}

\begin{abstract}
Abstrak
Penelitian ini bertujuan untuk mengetahui pengaruh yang signifikan pada penerapan strategi index card match terhadap hasil belajar tematik peserta didik kelas IV SD Negeri 8 Metro Timur. Penelitian ini menggunakan jenis penelitian eskperimen. Desain penelitian yang digunakan yaitu non-equivalent control group design. Populasi penelitian berjumlah 40 orang peserta didik. Sampel penelitian ditentukan menggunakan sampel jenuh dengan jumlah 40 orang peserta didik. Teknik pengumpulan data dilakukan dengan teknik tes dan non tes. Hasil penelitian menunjukkan terdapat pengaruh yang signifikan pada penerapan strategi index card match terhadap hasil belajar dengan $\mathrm{N}$-Gain 0,56 termasuk dalam kategori "sedang" yang ditunjukkan dengan pengujian hipotesis menggunakan rumus $t$-test pooled varians.
\end{abstract}

Kata kunci: hasil belajar tematik, index card match

Abstract

This study aims to determine the significant effect on the application of the index card match strategy on the thematic learning outcomes of class IV SD Negeri 8 Metro Timur students. This research uses experimental research. The research design used was the non-equivalent control group design. The study population was 40 students. The research sample was determined using a saturated sample with a total of 40 students. The data collection technique was done by using test and non-test techniques. The results showed that there was a significant effect on the application of the index card match strategy on learning outcomes with an N-Gain of 0.56, which was included in the "medium" category as indicated by hypothesis testing using the pooled variance t-test formula.

Keywords: thematic learning outcomes, index card match

Copyright (c) 2020 Ika Wulandari Utamining Tias, Bella Dwi Putri, Dian Pratiwi

$\triangle$ Corresponding author

Address : Jl Jambu RT 18 RW 06 Tejosari Kota Metro

ISSN 2580-3735 (Media Cetak)

Email : ika.wulandari84@fkip.unila.ac.id

ISSN 2580-1147 (Media Online)

Phone : 081368349208

DOI: https://doi.org/10.31004/basicedu.v4i4.553 
1316 Pengaruh Strategi Pembelajaran Aktif Tipe Index Card Match Terhadap Hasil Belajar Peserta Didik di Sekolah Dasar - Ika Wulandari Utamining Tias, Bella Dwi Putri, Dian Pratiwi

DOI: https://doi.org/10.31004/basicedu.v4i4.553

\section{PENDAHULUAN}

Pendidikan adalah sarana penting dalam kehidupan manusia dalam membangun perkembangan potensi, kecakapan, dan karakteristik pribadi seseorang. Pendidikan dapat dilakukan secara formal maupun non formal. Pembelajaran adalah suatu usaha sadar, rumit dan disengaja yang dilakukan oleh pendidik untuk membuat siswa belajar dan mendapatkan hasil belajar yang baik serta bermanfaat dalam kehidupan sehari-hari (Situmorang \& Hasanah, 2016).

Tujuan pendidikan nasional dapat dicapai apabila dalam melaksanakan proses kegiatan pembelajaran, peserta didik menggunakan kurikulum yang sesuai sebagai acuan atau aturan yang telah ditetapkan. Kurikulum merupakan seperangkat rencana dan pengaturan mengenai tujuan, isi dan bahan pelajaran, serta cara yang digunakan sebagai pedoman penyelenggaraan kegiatan pembelajaran. Diberlakukannya kurikulum 2013 diharapkan dapat meningkatkan dan menyeimbangkan antara sikap spiritual, sosial, pengetahuan, dan keterampilan serta mampu menghasilkan manusia yang produktif, kreatif, inovatif, dan efektif.

Lemahnya proses pembelajaran adalah salah satu masalah yang dihadapi dalam pendidikan. Peserta didik diharuskan untuk mengingat berbagai informasi tanpa diberikan kemampuan untuk menghubungkannya dengan kehidupan mereka sehari-hari. Proses seperti ini menyebabkan kurang mendorong anak untuk mengembangkan kemampuannya. Akibatnya ketika siswa lulus dari sekolah, mereka pintar secara teoritis, tetapi kemampuan dalam menerapkan materi dalam kehidupan sehari-hari rendah. Guru sebagai pendidik membutuhkan keahlian atau kecakapan dalam menyampaikan materi kepada siswanya agar siswa dengan mudah dapat memahami materi yang disampaikan oleh (Silberman, 2016) dalam (Situmorang \& Hasanah, 2016). Pada kenyataannya di sekolah proses pembelajaran masih terpusat pada guru. Banyaknya strategi pembelajaran yang hampir sama terkadang membuat guru menjadi enggan untuk menerapkan strategi pembelajaran aktif dalam proses pembelajaran. Tidak semua strategi pembelajaran aktif dapat diterapkan atau sesuai dengan materi yang akan diajarkan.

Sejalan dengan permasalahan di atas, berdasarkan hasil observasi, wawancara dan dokumentasi yang dilakukan peneliti di kelas IV SD Negeri 8 Metro Timur pada bulan November 2019 didapatkan data hasil mid semester ganjil tahun pelajaran 2019/2020 diperoleh data secara keseluruhan hasil mid semester ganjil kelas IV SD Negeri 8 Metro Timur masih tergolong rendah. Rendahnya hasil belajar tersebut disebabkan karena proses pembelajaran yang terjadi di kelas, guru lebih banyak menjelaskan dan belum melibatkan peserta didik dalam kegiatan belajar (teacher centered). Kurang aktifnya peserta didik dalam proses pembelajaran disebabkan karena guru belum menciptakan suasana belajar yang efektif dan menyenangkan. Pendidik juga belum menerapkan model atau strategi pembelajaran yang bervariasi, sehingga hasil belajar peserta didik rendah. Berikut ini data yang diperoleh 
1317 Pengaruh Strategi Pembelajaran Aktif Tipe Index Card Match Terhadap Hasil Belajar Peserta Didik di Sekolah Dasar - Ika Wulandari Utamining Tias, Bella Dwi Putri, Dian Pratiwi

DOI: https://doi.org/10.31004/basicedu.v4i4.553

tentang hasil belajar tematik peserta didik yang disajikan pada tabel 1 sebagai sebagai berikut

Tabel 1. Data Nilai Mid Semester Ganjil Pembelajaran Tematik SD Negeri 8 Metro Timur Tahun Pelajaran 2019/2020

\begin{tabular}{|c|c|c|c|c|c|c|}
\hline \multirow{2}{*}{ No. } & \multirow{2}{*}{ Kelas } & \multirow{2}{*}{ KKM } & \multicolumn{2}{|c|}{$\begin{array}{c}\text { Jumlah Peserta } \\
\text { didik }\end{array}$} & \multicolumn{2}{|c|}{ Persentase } \\
\hline & & & Tuntas & $\begin{array}{l}\text { Belum } \\
\text { Tuntas }\end{array}$ & Tuntas & $\begin{array}{l}\text { Belum } \\
\text { Tuntas }\end{array}$ \\
\hline & IV A & \multirow{3}{*}{75} & 6 & 14 & $27,73 \%$ & $72,27 \%$ \\
\hline & IV B & & 4 & 16 & $18,82 \%$ & $81,18 \%$ \\
\hline & IV C & & 8 & 12 & $36,64 \%$ & $63,36 \%$ \\
\hline \multicolumn{3}{|c|}{ Jumlah } & 18 & 42 & $27,73 \%$ & $72,27 \%$ \\
\hline
\end{tabular}

Berdasarkan Tabel 1, diperoleh data hasil ulangan tematik mid semester ganjil terdiri dari pembelajaran tematik diketahui bahwa hasil pembelajaran tematik kelas IV menunjukkan bahwa peserta didik masih banyak yang belum mencapai kriteria ketuntasan minimal (KKM) yaitu 75 . Terdapat $22,73 \%$ yang tuntas, $72,27 \%$ yang belum tuntas.

Salah satu faktor yang paling berpengaruh terhadap hasil belajar adalah ketidaksesuaian strategi pembelajaran. Strategi pembelajaran dapat diartikan sebagai cara yang dipergunakan oleh guru dalam mengadakan hubungan dengan siswa saat pembelajaran berlangsung (Situmorang \& Hasanah, 2016).

Menurut (Prawira et al., 2014), strategi pembelajaran aktif tipe index card match merupakan strategi yang menarik, karena menerapkan gabungan dari dua hal yaitu belajar dengan kemampuan masing-masing individu dan belajar kelompok. Strategi pembelajaran yang menuntut siswa untuk bekerja sama dan dapat meningkatkan rasa tanggung jawab siswa atas apa yang dipelajari dengan cara yang menyenangkan. Siswa saling bekerja sama dan saling membantu untuk menyelesaikan pertanyaan dan melemparkan pertanyaan kepada pasangan lain. Kegiatan belajar bersama ini dapat membantu memacu keaktifan belajar dan kemampuan untuk mengajar melalui kegiatan kerjasama kelompok kecil yang memungkinkan untuk memperoleh pemahaman dan penguasaan materi, sehingga tercapai hasil yang maksimal.

Strategi pembelajaran dengan index card match peserta didik dapat belajar dengan teman sebayanya, sehingga terbentuk kerjasama antar teman sebaya. Komunikasi antar peserta didik akan terbangun, hal ini juga akan melatih mereka dalam menghargai pendapat peserta didik yang lain. Pembelajaran juga tidak berlangsung searah, karena ada transfer ilmu dari guru ke peserta didik maupun antar peserta didik. Saat proses pembelajaran peserta didik tidak akan merasa jenuh, karena tidak terus menerus ada di tempat duduknya. Dengan menerapkan model pembelajaran ini agar terwujudnya menghidupkan suasana kelas, belajar yang menyenangkan, yang meningkatnya keaktifan siswa dalam pembelajaran (Annisa \& Marlina, 2019).

Berdasarkan pemaparan yang telah dikemukakan, adapun permasalahan yang dapat diajukan yaitu apakah ada perbedaan yang signifikan hasil belajar peserta didik yang menerapkan strategi pembelajaran aktif tipe index card match dengan peserta yang belajar melalui pembelajaran dengan pendekatan saintifik. Tujuan yang ingin dicapai yaitu untuk mengetahui pengaruh yang signifikan hasil belajar antara 
1318 Pengaruh Strategi Pembelajaran Aktif Tipe Index Card Match Terhadap Hasil Belajar Peserta Didik di Sekolah Dasar - Ika Wulandari Utamining Tias, Bella Dwi Putri, Dian Pratiwi

DOI: https://doi.org/10.31004/basicedu.v4i4.553

peserta didik yang belajar melalui strategi pembelajaran aktif tipe index card match dengan peserta didik melalui pembelajaran dengan pendekatan saintifik di kelas IV SD Negeri 8 Metro Timur.

\section{METODE}

Jenis penelitian ini merupakan penelitian eksperimen. Penelitian ini menggunakan desain non-equivalent control group design. Desain nonequivalent control group design menggunakan 2 kelompok, yaitu kelompok kelas eksperimen dan kelompok kelas kontrol. Desain penelitian nonequivalent control group design dapat digambarkan sebagai berikut.

\begin{tabular}{|c|c|c|}
\hline $\mathrm{O}_{1}$ & $X$ & $\mathrm{O}_{2}$ \\
\hline $\mathrm{O}_{3}$ & & $\mathrm{O}_{4}$ \\
\hline
\end{tabular}

Sumber: (Sugiyono, 2015)

Gambar 1. Desain Eksperimen.

Keterangan :

$\mathrm{O} 1$ = Nilai pre-test kelas eksperimen

$\mathrm{O} 2$ = Nilai post-test kelas eksperimen

O3 = Nilai pre-test kelas kontrol

O4 = Nilai post-test kelas control

$\mathrm{X}=$ Perlakuan strategi pembelajaran aktif tipe index card match.

Peserta didik pada penelitian ini dibedakan menjadi dua kelas, yaitu kelas eksperimen yang mendapatkan perlakuan dengan strategi index card match, dan kelas kontrol yang mendapatkan perlakuan dengan pendekatan saintifik. Penelitian dilaksanakan sebanyak $2 x$ pertemuan pada masingmasing kelas. Selama proses pembelajaran kedua kelas mendapatkan materi pelajaran yang sama, perbedaannya hanya terletak pada strategi pembelajaran yang digunakan.

Penelitian dilaksanakan di SD Negeri 8 Metro Timur, yang beralamat di Jl. Stadion Tejosari 24, Kecamatan Metro Timur, Kota Metro. Penelitian ini memiliki 2 variabel yaitu variabel bebas (independent) dan variabel terikat (dependent). Menurut (Sugiyono, 2015) variabel penelitian adalah suatu atribut, sifat, nilai dari orang atau objek yang mempunyai variasi yang diterapkan oleh peneliti untuk dipelajari dan kemudian ditarik kesimpulan. Variabel yang digunakan dalam penelitian ini terdiri dari variabel bebas yaitu strategi pembelajaran aktif tipe index card match $(\mathrm{X})$. Sedangkan variabel terikat pada penelitian ini adalah hasil belajar tematik peserta $\operatorname{didik}(\mathrm{Y})$.

Penelitian ini diawali dengan observasi, wawancara dan dokumentasi pada bulan oktober 2019. Penelitian dilaksanakan pada semester genap tahun pelajaran 2019/2020, subjek penelitian adalah peserta didik kelas IV. Prosedur penelitian memberikan gambaran serta memudahkan peneliti dalam melakukan penelitian. Tahap-tahap pelaksanaan penelitian eksperimen ini yaitu (1) melakukan penelitian pendahuluan, observasi dan studi dokumentasi, (2) menentukan dua kelompok kelas belajar untuk dijadikan subjek penelitian, kelas eksperimen (IVB) dan kelas kontrol (IVA) SD Negeri 8 Metro Timur, (3) menyusun kisi-kisi dan instrumen pengumpul data berupa tes pilihan jamak, (4) menguji coba instrumen tes kepada subjek uji coba soal, yaitu peserta didik kelas (IVA) SD Negeri 8 Metro Timur, (5) menganalisis 
1319 Pengaruh Strategi Pembelajaran Aktif Tipe Index Card Match Terhadap Hasil Belajar Peserta Didik di Sekolah Dasar - Ika Wulandari Utamining Tias, Bella Dwi Putri, Dian Pratiwi

DOI: https://doi.org/10.31004/basicedu.v4i4.553

data uji coba instrumen untuk mengetahui valid dan reliabel yang dijadikan sebagai soal pre-test dan post-test, (6) memberikan pre-test pada peserta didik eksperimen dan kelas kontrol untuk mengetahui kemampuan awal peserta didik, (7) melaksanakan pembelajaran dengan memberikan perlakuan pada kelas eksperimen menggunakan strategi index card match sedangkan pada kelas kontrol menggunakan pendekatan saintifik. (8) memberikan post-test pada kelas eksperimen dan kelas kontrol untuk mengetahui hasil belajar peserta. didik, (9) menganalisis data hasil tes dengan menghitung perbedaan antara hasil pre-test dan post-test untuk masing-masing kelas, (10) menggunakan perhitungan manual statistik dengan bantuan Microsoft Office Excel 2010 untuk mencari perbedaan hasil penelitian, sehingga diketahui pengaruh penggunaan strategi index card match terhadap hasil belajar tematik peserta didik kelas IV SD Negeri 8 Metro Timur, (11) interpretasi hasil perhitungan data.

Populasi pada penelitian ini adalah peserta didik kelas IV SD Negeri 8 Metro Timur, terdiri dari dua kelas, yaitu IVA dan IVB. Kelas IVA berjumlah 20 ' orang peserta didik dan kelas IVB berjumlah 20 orang peserta didik, jumlah total populasi 40 orang peserta didik. Teknik pengambilan sampel dalam penelitian ini menggunakan non probability sampling, teknik pengambilan sampel yang tidak memberi peluang/kesempatan sama bagi setiap unsur atau anggota populasi untuk dipilih menjadi sampel, sedangkan jenis sampel yang digunakan dalam penelitian ini adalah sampel jenuh.
Teknik pengumpulan data yang digunakan dalam penelitian ini adalah non tes (observasi, wawancara dan dokumentasi) dan tes. Observasi dilakukan untuk memperoleh data kondisi sekolah dan pelaksanaan pembelajaran di SD Negeri 8 Metro Timur. Wawancara digunakan untuk mengumpulkan data empiris mengenai proses pembelajaran tematik.

Dokumentasi dilaksanakan untuk mengumpulkan data berupa nilai, profil sekolah dan foto proses kegiatan penelitian. Tes dilakukan untuk menilai pengetahuan peserta didik sebelum di mulai pembelajaran. Pengambilan data dilaksanakan pada saat sebelum pembelajaran dimulai. Bentuk tes yang diberikan berupa soal pilihan jamak yang terdiri dari 20 butir soal. Sebelum diberikan kepada peserta didik, soal tes diuji terlebih dahulu validitas dan reliabilitas, agar dapat digunakan sebagai soal pre-test dan posttest.

Teknik analisis data pada penelitian ini adalah uji normalitas, uji homogenitas, dan uji hipotesis. Hipotesis yang diajukan dalam penelitian ini adalah terdapat pengaruh yang signifikansi pada penerapan strategi pembelajaran index card match terhadap hasil belajar peserta didik kelas IV SD Negeri 8 Metro Timur. Beberapa rumus yang digunakan dalam penelitian ini adalah sebagai berikut.

Menghitung nilai hasil belajar peserta didik ranah kognitif secara individu dengan rumus sebagai berikut.

$$
\mathrm{S}=\mathrm{R} / \mathrm{N} \quad \mathrm{X} 100
$$

Keterangan: 
1320 Pengaruh Strategi Pembelajaran Aktif Tipe Index Card Match Terhadap Hasil Belajar Peserta Didik di Sekolah Dasar - Ika Wulandari Utamining Tias, Bella Dwi Putri, Dian Pratiwi

DOI: https://doi.org/10.31004/basicedu.v4i4.553

$\mathrm{S} \quad=$ Nilai peserta didik (nilai yang dicari)

$\mathrm{R} \quad=$ Jumlah skor/item yang dijawab benar

$\mathrm{N} \quad=$ Skor maksimum dari tes

100 = Bilangan tetap

Sumber: (Purwanto, 2008)

Menghitung nilai rata-rata seluruh peserta didik dengan rumus sebagai berikut.

$$
\mathrm{X}=(\Sigma \mathrm{X}) / \Sigma \mathrm{N}
$$

Keterangan:

$\mathrm{X}=$ nilai rata-rata seluruh peserta didik

$\Sigma \mathrm{X}=$ jumlah nilai yang diperoleh peserta didik

$\Sigma \mathrm{N}=$ jumlah peserta didik

Sumber: (Aqib, 2014)

Menghitung persentase ketuntasan hasil belajar peserta didik secara klasikal dengan rumus sebagai berikut.

$\mathrm{P}=(\Sigma$ peserta didik yang tuntas belajar $) /(\Sigma$ peserta didik) x $100 \%$

\section{HASIL DAN PEMBAHASAN}

Sebelum disajikan deskripsi data variabel Y (hasil belajar peserta didik seteleh perlakuan), berikut ini disajikan data tentang perbandingan nilai pre-test, post-test, dan $N$-Gain kelas kelas eksperimen dan kelas kontrol. Berikut data nilai pre-test peserta didik kelas eksperimen dan kelas kontrol pada tabel 2.

Tabel 2. Nilai Pre-test Peserta Didik Kelas Eksperimen dan Kelas Kontrol

\begin{tabular}{|c|c|c|c|c|c|}
\hline No. & $\begin{array}{c}\text { Interval } \\
\text { Kelas }\end{array}$ & $\begin{array}{c}\text { Frekuensi } \\
\text { Kelas } \\
\text { Eksperimen }\end{array}$ & No. & $\begin{array}{c}\text { Interval } \\
\text { Kelas }\end{array}$ & $\begin{array}{c}\text { Frekuensi } \\
\text { Kelas } \\
\text { Kontrol } \\
\end{array}$ \\
\hline 1 & $40-47$ & 6 & 1 & $50-57$ & 2 \\
\hline 2 & $48-55$ & 4 & 2 & $58-65$ & 6 \\
\hline 3 & $56-63$ & 2 & 3 & $66-73$ & 3 \\
\hline 4 & $64-71$ & 4 & 4 & $74-81$ & 4 \\
\hline 5 & $72-79$ & 3 & 5 & $82-89$ & 2 \\
\hline 6 & $80-87$ & 1 & 6 & $90-97$ & 3 \\
\hline \multicolumn{2}{|c|}{ Jumlah } & 20 & \multicolumn{2}{|c|}{ Jumlah } & 20 \\
\hline \multicolumn{2}{|c|}{ Rata-rata } & 58 & \multicolumn{2}{|c|}{ Rata-rata } & 72,25 \\
\hline \multicolumn{2}{|c|}{ Tuntas (>75) } & 4 & \multicolumn{2}{|c|}{ Tuntas $(>75)$} & 9 \\
\hline \multicolumn{2}{|c|}{$\begin{array}{c}\text { Belum tuntas } \\
(<75)\end{array}$} & 16 & \multicolumn{2}{|c|}{$\begin{array}{c}\text { Belum tuntas } \\
(<75)\end{array}$} & 11 \\
\hline \multicolumn{2}{|c|}{$\begin{array}{l}\text { Persentase } \\
\text { Ketuntasan }\end{array}$} & $20 \%$ & \multicolumn{2}{|c|}{$\begin{array}{l}\text { Persentase } \\
\text { Ketuntasan }\end{array}$} & $45 \%$ \\
\hline
\end{tabular}

Berdasarkan Tabel 2, dapat diketahui bahwa peserta didik yang tuntas pada kelas eksperimen sebanyak 4 peserta didik dan yang belum tuntas sebanyak 16 peserta didik dari jumlah keseluruhan 20 peserta didik dengan persentase ketuntasan sebesar $20 \%$ dan nilai ratarata 58. Peserta didik yang tuntas pada kelas kontrol sebanyak 9 peserta didik dan yang belum tuntas sebanyak 11 peserta didik dari jumlah keseluruhan 20 peserta didik dengan persentase ketuntasan sebesar $43 \%$ dan nilai rata-rata 72,25. Penggolongan nilai rata-rata dari kedua kelas tersebut dapat digambarkan dalam gambar 1 berikut:

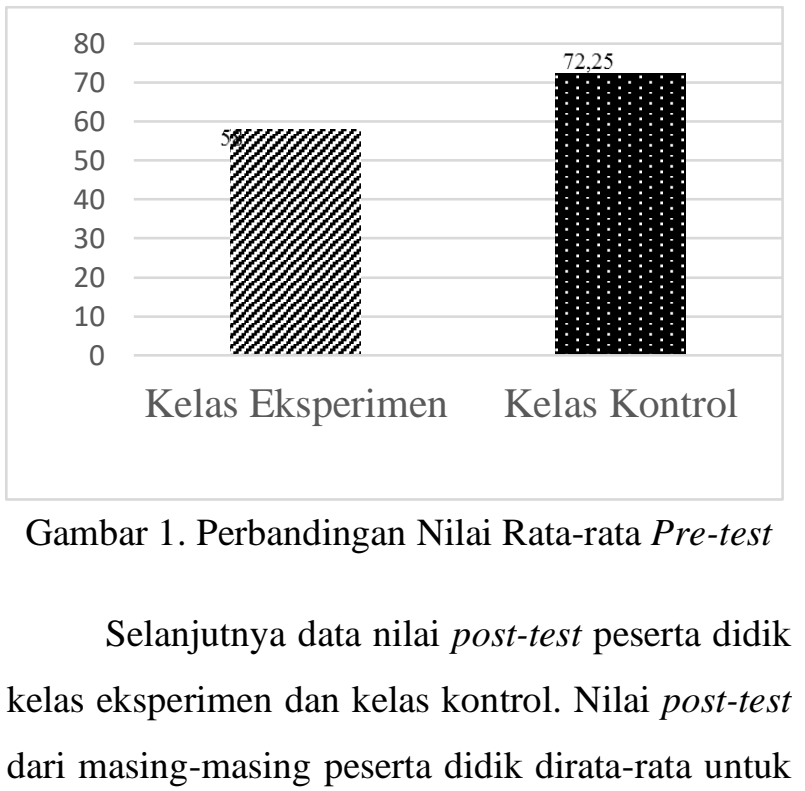


1321 Pengaruh Strategi Pembelajaran Aktif Tipe Index Card Match Terhadap Hasil Belajar Peserta Didik di Sekolah Dasar - Ika Wulandari Utamining Tias, Bella Dwi Putri, Dian Pratiwi

DOI: https://doi.org/10.31004/basicedu.v4i4.553

mengetahui hasil belajar peserta didik setelah adanya perlakuan yang diberikan pada akhir pembelajaran. Nilai post-test di kedua kelas ditampilkan pada tabel 3 .

Tabel 3. Nilai Post-test Peserta didik Kelas Eksperimen Kelas Kontrol

\begin{tabular}{|c|c|c|c|c|c|}
\hline No. & $\begin{array}{c}\text { Interval } \\
\text { Kelas }\end{array}$ & $\begin{array}{c}\text { Frekuensi } \\
\text { Kelas } \\
\text { Eksperimen }\end{array}$ & No. & $\begin{array}{c}\text { Interval } \\
\text { Kelas }\end{array}$ & $\begin{array}{c}\text { Frekuensi } \\
\text { Kelas } \\
\text { Kontrol }\end{array}$ \\
\hline 1 & $65-71$ & 5 & 1 & $60-66$ & 2 \\
\hline 2 & $72-78$ & 3 & 2 & $67-73$ & 4 \\
\hline 3 & $79-85$ & 4 & 3 & $74-80$ & 5 \\
\hline 4 & $86-92$ & 3 & 4 & $81-87$ & 3 \\
\hline 5 & 93-99 & 3 & 5 & $88-94$ & 2 \\
\hline 6 & 100-106 & 2 & 6 & 95-101 & 1 \\
\hline \multicolumn{2}{|c|}{ Jumlah } & 20 & \multicolumn{2}{|c|}{ Jumlah } & 20 \\
\hline \multicolumn{2}{|c|}{ Rata-rata } & 82,25 & \multicolumn{2}{|c|}{ Rata-rata } & 80 \\
\hline \multicolumn{2}{|c|}{ Tuntas $(>75)$} & 15 & \multicolumn{2}{|c|}{ Tuntas (>75) } & \\
\hline \multicolumn{2}{|c|}{$\begin{array}{c}\text { Belum tuntas } \\
(<75 \%)\end{array}$} & 5 & \multicolumn{2}{|c|}{$\begin{array}{c}\text { Belum tuntas } \\
(<75 \%)\end{array}$} & \\
\hline \multicolumn{2}{|c|}{$\begin{array}{l}\text { Persentase } \\
\text { Ketuntasan }\end{array}$} & $75 \%$ & \multicolumn{2}{|c|}{$\begin{array}{l}\text { Persentase } \\
\text { Ketuntasan }\end{array}$} & $70 \%$ \\
\hline
\end{tabular}

Berdasarkan Tabel 3, dapat diketahui bahwa peserta didik yang tuntas pada post-test kelas eksperimen sebanyak 15 peserta didik dan yang belum tuntas sebanyak 5 peserta didik dari jumlah keseluruhan 20 peserta didik dengan persentase ketuntasan sebesar $75 \%$ dan nilai rata-rata 82,25. Peserta didik yang tuntas pada post-test kelas kontrol sebanyak 14 peserta didik dan yang belum tuntas sebanyak 6 peserta didik dari jumlah keseluruhan 20 peserta didik dengan persentase ketuntasan sebesar $75 \%$ dan nilai rata- rata 82,25. Penggolongan nilai rata-rata dari kedua kelas tersebut dapat digambarkan dalam gambar 2 . sebagai berikut:

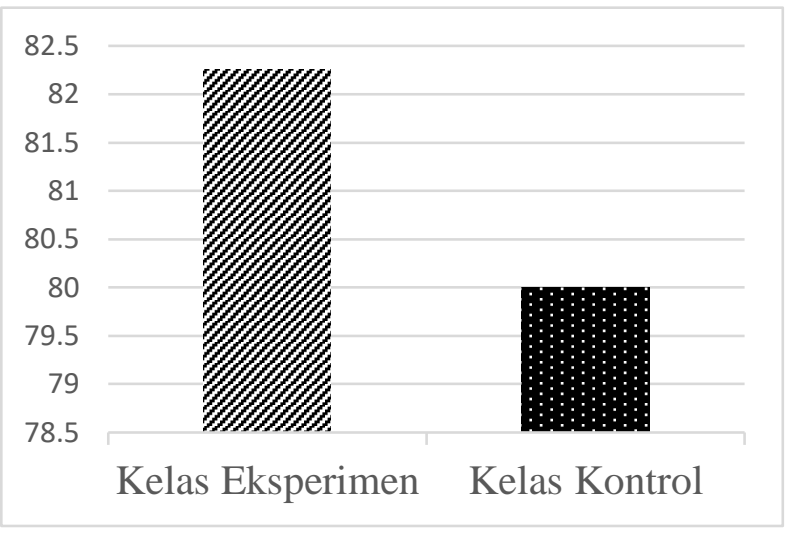

Gambar 2. Perbandingan Nilai Rata-rata Post-Test

Diketahui bahwa ada perbedaan nilai ratarata antara kelas eksperimen dan kelas kontrol. Kelas eksperimen menggunakan strategi index card match dan di kelas kontrol menggunakan pendekatan saintifik. Setelah diketahui nilai pretest dan post-test pada kedua kelas, selanjutnya melakukan perhitungan $\mathrm{N}$-Gain untuk mengetahui pe-ningkatan nilai setelah diberi perlakuan. Klasifikasi nilai $N$-Gain peserta didik kelas eksperimen dan kelas kontrol dapat dilihat pada tabel 4 sebagai berikut:

Tabel 4. Klasifikasi Nilai $N$-Gain Peserta Didik Kelas Eksperimen dan Kelas Kontrol

\begin{tabular}{|c|c|c|c|c|c|}
\hline \multirow[b]{2}{*}{ No } & \multirow[b]{2}{*}{ Kategori } & \multicolumn{2}{|c|}{ Frekuensi } & \multicolumn{2}{|c|}{ N-Gain } \\
\hline & & Eksperimen & Kontrol & Eks & Kontrol \\
\hline 1. & Tinggi & 2 & 3 & \multirow{3}{*}{0,56} & \multirow{3}{*}{0,30} \\
\hline 2. & Sedang & 10 & 5 & & \\
\hline 3. & Rendah & 8 & 12 & & \\
\hline
\end{tabular}

Berdasarkan tabel 4 dapat dilihat bahwa nilai rata-rata $N$-Gain kelas eksperimen sebesar 0,56 dengan kategori sedang sedangkan kelas kontrol sebesar 0,30 dengan kategori rendah. Perbandingan nilai rata-rata $N$-Gain kelas 
1322 Pengaruh Strategi Pembelajaran Aktif Tipe Index Card Match Terhadap Hasil Belajar Peserta Didik di Sekolah Dasar - Ika Wulandari Utamining Tias, Bella Dwi Putri, Dian Pratiwi

DOI: https://doi.org/10.31004/basicedu.v4i4.553

eksperimen dan kelas kontrol dapat digambarkan dalam gambar 3 sebagai berikut:

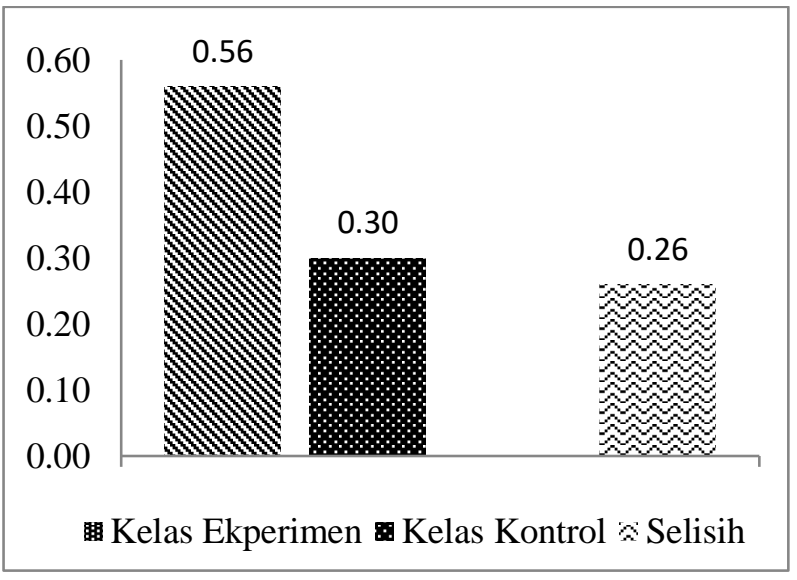

Gambar 3. Diagram Perbandingan Nilai Rata-rata $N$-Gain

\section{Hasil Uji Normalitas}

Uji normalitas dilakukan untuk mengetahui apakah data dari kedua kelas berasal dari populasi yang berdistribusi normal atau tidak. Data yang diuji normalitas dalam penelitian ini adalah data hasil post-test (setelah perlakuan). Uji normalitas dilakukan untuk mengetahui apakah data dari kedua kelas berasal dari populasi yang berdistribusi normal atau tidak dan menggunakan rumus chi kuadrat dengan bantuan program Microsoft Office Excel 2010. Interpretasi hasil perhitungan dilakukan dengan membandingkan $\chi 2$ hitung dengan $\chi 2$ tabel untuk $\alpha=0,05$ dengan $\mathrm{dk}=\mathrm{k}-1$.

Berdasarkan perhitungan uji normalitas pretest eksperimen dan kontrol, diperoleh nilai $\chi 2$ hitung $=5,601<\chi 2$ tabel $=11,070$ berarti data berdistribusi normal. Perhitungan uji normalitas nilai post-test kelas eksperimen dan kontrol diperoleh bahwa nilai $\chi 2$ hitung $=7,998<\chi 2$ tabel $=$ 11,070 berarti data berdistribusi normal .
Berdasarkan hasil di atas dapat disimpulkan bahwa data nilai pre-test dan post-test untuk kelas kelas eksperimen dan kelas kontrol berdistribusi normal.

\section{Hasil Uji Homogenitas}

Uji homogenitas dihitung dengan menggunakan rumus uji-F dengan Microsoft Excel Kaidah keputusan jika Fhitung < Ftabel maka varians homogen, sedangkan jika Fhitung $>$ Ftabel maka varians tidak homogen. Taraf signifikansi yang ditetapkan adalah 0,05 . Hasil perhitungan didapat nilai $\mathrm{F}$ untuk pre-test yaitu Fhitung $=1,06$ $<$ Ftabel $=2,17$ sedangkan untuk post-test Fhitung $=1,05<\mathrm{F}$ tabel $=2,17$. Berdasarkan perbandingan nilai $\mathrm{F}$ tersebut dapat disimpulkan bahwa populasi memiliki varian yang homogen.

\section{Hasil Uji Hipotesis}

Setelah dilakukan uji normalitas dan homogenitas diperoleh data berdistribusi normal dan memiliki varians yang sama, selanjutnya dilakukan pengujian hipotesis. Hasil perhitungan hipotesis menggunakan rumus uji t-test pooled varians karena jumlah anggota sampel 1 (kelas eksperimen) tidak sama dengan jumlah anggota sampel 2 (kelas kontrol) serta varian homogen.

Pengambilan keputusan diterima atau ditolaknya hipotesis yang diajukan dengan mengacu pada kaidah berikut. Jika Fhitung > Ftabel, artinya terdapat hubungan yang signifikan atau Ho ditolak dan Ha diterima, sedangkan jika Fhitung < Ftabel, artinya tidak terdapat hubungan yang signifikan atau Ho diterima dan Ha ditolak. 
1323 Pengaruh Strategi Pembelajaran Aktif Tipe Index Card Match Terhadap Hasil Belajar Peserta Didik di Sekolah Dasar - Ika Wulandari Utamining Tias, Bella Dwi Putri, Dian Pratiwi

DOI: https://doi.org/10.31004/basicedu.v4i4.553

Diketahui bahwa thitung $=5,257>$ ttabel $=$ 2,021, berarti hipotesis $\left(\mathrm{H}_{0}\right)$ diterima. Artinya "terdapat pengaruh yang signifikan pada strategi pembelajaran index card match terhadap hasil belajar tematik peserta didik kelas IV SD Negeri 8 Metro Timur.

\section{Pembahasan}

Perbedaan penelitian yang dilakukan dengan penelitian yang lain adalah melihat distribusi nilai pre-test dan post-test, serta menghitung pengaruh strategi pembelajaran tipe index card match dengan hasil belajar dan melihat perbedaan antara nilai sebelum percobaan dan sesudah percobaan dengan $N$-Gain .

Berdasarkan hasil perhitungan bahwa thitung $=5,257>$ ttabel $=2,021$, berarti hipotesis $\left(\mathrm{H}_{0}\right)$ diterima. Artinya "terdapat pengaruh yang signifikan pada strategi pembelajaran index card match terhadap hasil belajar tematik peserta didik kelas IV SD Negeri 8 Metro Timur menunjukkan bahwa strategi pembelajaran index card match dapat mempengaruhi hasil belajar peserta didik. Sejalan dengan pendapat (Silberman, 2016) bahwa strategi pembelajaran index card match merupakan suatu pembelajaran yang mengajak peserta didik untuk aktif dan mengingat kembali materi yang telah dipelajari oleh peserta didik, sehingga hasil belajar peserta didik dapat meningkat.

Strategi pembelajaran merupakan upaya seorang tenaga pendidik untuk menggerakkan peserta didik agar mau melakukan aktivitas pembelajaran, strategi pembelajaran bukanlah kegiatan yang sederhana, setiap langkahnya pembelajaran disertai penggerakan segala kemampuan untuk pencapaian tujuan pembelajaran. Pada dasarnya pembelajaran dengan model pendekatan memiliki kelebihan. Siswa dapat berpartisipasi aktif dalam pembelajaran yang disajikan, menumbuhkan sikap inquiry, mendukung kemampuan problem solving peserta didik, dan memberikan suatu wahana interaksi antar siswa maupun dengan pengajar, serta materi yang dipelajari dapat mencapai tingkat kemampuan yang lebih lama membekas karena peserta didik dilibatkan dalam proses menemukannya (N. E. Anggraeni, 2019).

Menurut (Hartiningrum \& Ula, 2019) strategi pembelajaran index card match digunakan untuk mengerjakan latihan soal agar siswa tidak merasa bosan dan jenuh dalam pengerjaan soal, sehingga siswa tidak sadar bahwa dalam mencari pasangan kartu itu siswa masih dalam proses pembelajaran. Penggunaan index card match juga dapat digunakan untuk melihat sejauh mana pemahaman siswa tentang materi yang diajarkan.

Adapun kelebihan strategi pembelajaran index card match menurut (Suprijono, 2013) yaitu, menciptakan suasana yang penuh semangat dalam belajar, Mampu meningkatkan hasil belajar peserta didik, strategi index card match merupakan strategi menyenangkan yang digunakan untuk memantapkan pengetahuan peserta didik terhadap materi yang telah dipelajari.

Hasil penelitian menunjukan bahwa strategi pembelajaran tipe index card match meningkatkan hasil belajar, terlihat dari hasil $N$-Gain yang diperoleh yaitu sebesar 0,56 dengan kategori sedang hal ini menunjukkan bahwa hal tersebut terjadi karena dengan strategi pembelajaran aktif 
1324 Pengaruh Strategi Pembelajaran Aktif Tipe Index Card Match Terhadap Hasil Belajar Peserta Didik di Sekolah Dasar - Ika Wulandari Utamining Tias, Bella Dwi Putri, Dian Pratiwi

DOI: https://doi.org/10.31004/basicedu.v4i4.553

tipe index card match dapat melatih pola pikir siswa karena dengan strategi ini siswa dilatih memahami dan mempelajari suatu konsep atau topik melalui pencarian kartu jawaban atau soal, Lalu mendiskusikan hasil pencarian pasangan kartu yang sudah cocok oleh peserta didik bersama-sama dengan guru. Strategis pembelajaran ini dilakukan dalam suasana menyenangkan, maka siswa diharapkan lebih bersemangat dan dapat menguasai materi dengan baik. Belajar yang baik adalah siswa mampu menangkap informasi dari guru secara baik dan jelas, siswa dengan fokus menyimak informasi dari guru sehingga dapat menerima dan menyimpan memori secara utuh, sehingga jika dilakukan evaluasi maka hasilnya akan tinggi. Guru sebagai unsur terdepan dalam pembelajaran sangat berpengaruh dalam terciptanya suasana pembelajaran yang kondusif, hal tersebut juga didukung dengan penggunaan metode dan pemakaian media belajar yang tepat maka akan tercipta kelas yang baik dalam pembelajaran dan perdampak pada peningkatan hasil belajar siswa (Sirait \& Apriyani, 2020).

Sejalan dengan hal ini, menurut $(\mathrm{H}$. Anggraeni, 2017), keunggulan dari index card match yakni menciptakan susana belajar yang aktif dan menyenangkan, materi lebih mudah untuk dipahami, pembelajaran tidak membosankan atau lebih bervariasi serta peserta didik lebih cermat sehingga, dapat meningkatkan kemampuan peserta didik. Selain itu, melalui kegiatan strategi pembelajaran aktif tipe index card match melibatkan peran peserta didik secara aktif dalam pembelajaran untuk menemukan konsep atau prinsip materi pembelajaran. Peserta didik dapat mengembangkan kemampuan berpikir dan kreatifitas ilmiah secara optimal karena siswa diberi kesempatan untuk mengalami sendiri atau melakukan sendiri dalam kegiatan pembelajaran (Prawira et al., 2014).

\section{SIMPULAN}

Berdasarkan hasil analisis data dan pembahasan penelitian, dapat disimpulkan bahwa terdapat pengaruh strategi pembelajaran index card match terhadap hasil belajar tematik peserta didik kelas IV SD Negeri 8 Metro Timur. Pengaruhnya dapat dilihat dari perbedaan hasil belajar antara kelas eksperimen dan kelas kontrol. Nilai rata-rata pre-test kelas eksperimen adalah 58, sedangkan rata-rata pre-test kelas kontrol adalah 72,25 . Nilai rata-rata post-test kelas ekperimen adalah 82,25 sedangkan kelas kontrol adalah 80 . Begitu pula dapat dilihat dari perbandingan rata-rata $N$-Gain kelas eksperimen adalah 0,56, sedangkan rata-rata $N$-Gain kelas kontrol adalah 0,30 , keduanya berkategori "sedang". Hasil pengujian hipotesis menggunakan rumus t-test diperoleh data t hitung sebesar 5,257 sedangkan t tabel sebesar 2,021, perbandingan tersebut menunjukkan $(5,257>2,021)$ berarti Ha diterima. Dapat disimpulkan bahwa terdapat pengaruh yang signifikan pada penerapan strategi index card match terhadap hasil belajar tematik peserta didik kelas IV SD Negeri 8 Metro Timur.

\section{DAFTAR PUSTAKA}

Anggraeni, H. (2017). PENGARUH MODEL PEMBELAJARAN KOOPERATIF TIPE ICM (INDEX CARD MATCH) 
1325 Pengaruh Strategi Pembelajaran Aktif Tipe Index Card Match Terhadap Hasil Belajar Peserta Didik di Sekolah Dasar - Ika Wulandari Utamining Tias, Bella Dwi Putri, Dian Pratiwi

DOI: https://doi.org/10.31004/basicedu.v4i4.553

\begin{tabular}{llrr} 
TERHADAP & HASIL & BELAJAR & SISWA \\
MATERI & KEGIATAN & EKONOMI \\
BERDASARKAN & \multicolumn{3}{r}{ TEMPAT } \\
TINGGALNYA & KELAS & IV & SDN \\
BABATAN 1 & SURABAYA. & Jurnal \\
Penelitian Pendidikan Guru Sekolah Dasar.
\end{tabular}

Anggraeni, N. E. (2019). STRATEGI PEMBELAJARAN DENGAN MODEL PENDEKATAN PADA PESERTA DIDIK AGAR TERCAPAINYA TUJUAN PENDIDIKAN DI ERA GLOBALISASI. ScienceEdu.

https://doi.org/10.19184/se.v2i1.11796

Annisa, F., \& Marlina, M. (2019). PENERAPAN MODEL PEMBELAJARAN KOOPERATIF TIPE INDEX CARD MATCH TERHADAP AKTIVITAS DAN HASIL BELAJAR MATEMATIKA PESERTA DIDIK. Jurnal Basicedu.

https://doi.org/10.31004/basicedu.v3i4.209

Aqib, Z. (2014). Penelitian Tindakan Kelas Untuk guru $S D$, SLB , TK. CV. Yrama Widya.

Hartiningrum, E. S. N., \& Ula, N. S. (2019). Pengaruh Model Pembelajaran Kooperatif Tipe Index Card Match terhadap Hasil Belajar Matematika Siswa. Al-Khwarizmi: Jurnal Pendidikan Matematika Dan Ilmu Pengetahuan

Alam. https://doi.org/10.24256/jpmipa.v7i2.707

Prawira, S. N. P. S., Zulaikha, S., \& Negara, I. G. A. O. (2014). PENGARUH PENERAPAN STRATEGI PEMBELAJARAN AKTIF TIPE INDEX CARD MATCH TERHADAP HASIL BELAJAR IPS SISWA SD. EJournal Mimbar PGSD Universitas Pendidikan Ganesha. https://doi.org/http://dx.doi.org/10.23887/jjpg sd.v2i1.2030

Purwanto, N. (2008). Prinsip-prinsip dan Teknik Evaluasi Pengajaran. Remaja Rosdakarya.

Silberman, M. L. (2016). Active Learning 101 Cara Belajar Siswa Aktif. Nusamedia.

Sirait, E. D., \& Apriyani, D. D. (2020). PENGARUH PENGGUNAAN STRATEGI PEMBELAJARAN AKTIF ICM (INDEX CARD MATCH) TERHADAP HASIL BELAJAR MATEMATIKA. JPMI (Jurnal
Pendidikan Matematika Indonesia). https://doi.org/10.26737/jpmi.v5i1.1710

Situmorang, P. C., \& Hasanah, U. (2016). Perbedaan Hasil Belajar Siswa Menggunakan Strategi Pembelajaran Aktif Tipe Index Card Match dengan Card Sort Pada Materi Organisasi Kehidupan. Jurnal Pelita Pendidikan.

Sugiyono. (2015). Metode Penelitian Pendidikan Pendekatan Kuantitatif, Kualitatif, dan R\&D. CV Alfabeta.

Suprijono, A. (2013). Coopretive Learning (Teori dan Aplikasi PAIKEM). Pustaka Belajar. 